\title{
On the syntax of anticausativisation and decausativisation in Japanese and Chinese
}

\author{
Wenchao Li
}

School of International Studies, Zhejiang University

Yuhangtang Road \# 866, Hangzhou city, China, Postal Code: 310058

\section{ABSTRACT}

This paper is dedicated to a comparison of transitive/intransitive verb alternation in Japanese and Chinese. Discussions are focused upon three grammatical elements: monosyllabic verbs, compound verbs and constructions. The findings reveal that the two languages share similarities in two aspects: (i). transitive and intransitive verbs share the same word form; (ii) transitive and intransitive verbs can derive from the same adjective stems. Significant distinctions are also seen between the two: anticausativisation and decausativisation in Japanese are mainly facilitated in morphological level, e.g. anticausativisation is realised through the morpheme '-e-' and decausativisation is conveyed by '-ar-'. The morpheme '-e-" can be used with both intransitive and transitive verbs. Regarding Chinese, lexical and syntax have a curial role to play in transitive/intransitive verb alternation. Decausativisation appears the most favourable strategy of the alternation. Two ways of decausativisation is observed: schema of [action + resultative state]; verb compounds (V-V). Three types of V-Vs are possible for this strategy, i.e. Predicate-Complement V-V, Modifier-Head V-V and Coordinative V-V. Among them, predicate-complement $\mathrm{V}-\mathrm{V}$ has the largest token of decausativisation. Moreover, constraints on Chinese anticausativisation and decausativisation are seen. When a resultative complment predicate an internal argument, the higher the agentivity that implies manner of action, the greater the unlikelihood of anticausativisation. In decausativisation, the internal argument that accepts the change of state is limited to the 'possessive relationship'.

Keywords: anticausativisation; decausativisation; Japanese, Chinese

\section{Council for Innovative Research}

Peer Review Research Publishing System

\section{Journal: Journal of Advances in Linguistics}

Vol .5 No 3

editor@cirjal.com, www.cirjal.com 


\section{ISSN 2348-3024}

\section{Introduction}

The study of transitive/intransitive verb alternation has long been an overriding issue in Japanese linguistics (e.g. Kageyama 1993, 1996; Maruta 1998; Okutsu 1967; Suga 2000). A variety of perspectives have been devoted to this subject, i.e. semantic structure, argument structure, aspect, voice, etc. Japanese transitive/intransitive verb alternation is of two types:

(1) a. The transitive and intransitive verbs share the same word form.

e.g. hira-ku (doa -wo-hiraku 'open the door' / doa-ga-hiraku 'the door is open')

b. A morpheme that indicates intransitive and transitive properties is added to the verb stem,

e.g. kowa-s-(r)u/kowa-re-ru and kir-0/-(r)u/kir-e-ru.

Type (1a) is very rare, apart from hiraku, only one verb that bears both transitivity and intransitivity, i.e. maku, (e.g. Asakao ga tsuru o maku/asakao no tsutu ga maku).

Transitive/intransitive verb alternation in Chinese is of two types:

(2) a. The transitive and intransitive verbs share the same word form.

e.g. 开 kai, men-kai 'the door is open', 开门 kai-men 'open the door'

b. The transitive and intransitive alternation occurs according to the combination with other verbs.

e.g. 坏 huai 'broken', 切 qie 'cut'

The majority of verb alternation goes to type (b). For instance, 坏 huai 'broken' is often used as a light verb (3a). It can also appear with the light verb 弄 nong, which corresponds to do in English and suru in Japanese (3b).

(3) a. 计算机 坏 了

Jisuanji huai le

computer break- PERF.

'The computer broke.'

b. 张三 弄坏 了 计算机

Zhang San nong-huai le jisuanji

Zhang San do-break PERF computer

'Zhang San broke the computer.'

Moreover, 坏 huai lacks transitivity, therefore (4) is ruled out.

(4) *张三 坏了 计算机 
Zhang San huai le jisuanji

'Zhang San broke the computer.'

Similar usage is found in 断 duan 'break', which cannot be used as a transitive verb unless a transitive verb, such as 折 zhe, is added, c.f. (5b), (5c).

(5) a. 树枝 断 了

Shuzhi duan le.

'The branch broke.'

b. *张三 断 了 树枝

Zhang San duan le shuzhi.

'Zhangsan broke the branch.'

c. 张三折断了树枝

Zhang San zhe-duan le shizhi.

'Zhangsan broke the branch.'

By contrary, the Chinese verb 切 qie only has transitivity, c.f. (6a), (6b). If a resultative complement, such as 好 hao, is added, it comes to bear unaccusativity $(7 \mathrm{c})$.

(7) a. 张三 切 蛋糕

Zhang San qie dangao.

Zhang San cut cake

'Zhang San is cutting a cake.'

b. *蛋糕 切了

Dangao qie le.

cake qie PERF

'The cake cut.'

C. 蛋糕 切好 了

Dangao qie-hao le.

cake cut-finish PERF

'The cake has been divided.' 
The lexical conceptual structures of 切, and 切好 is provided in (8).
(8) a. 切 qie

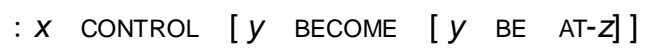
b. 切好 qie-hao
$: x$ CONTROL $\left[\begin{array}{lll}y & \text { BECOME }\end{array}\left[\begin{array}{lll}y & \text { BE } & \text { AT- } z\end{array}\right] \quad(x=y)\right.$

Given the above data, it appears then, that Japanese employs bound morphemes to convey transitive/intransitive verb alternation, which, in Chinese, is realised via free morphemes. If a complement representing state or result is added to a transitive verb, the transitivity of that verb is weakened, giving rise to transitive/intransitive verb alternation. At this stage, it may not be unsound to introduce another concept so as to preserve the typology: anticausativisation vs. decausativisation.

Anticausativisation: The object changes in terms of the property of the object itself. The transitive verb comes to bear an intransitive function via identifying the object and causer.

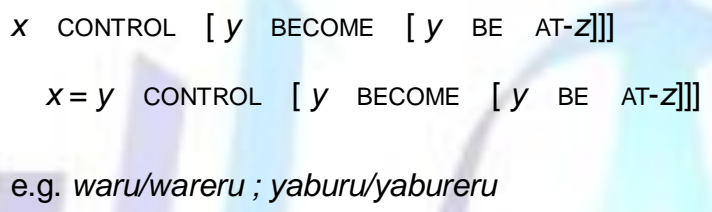

Decausativisation: The object changes in terms of external factors. The intransitivisation affix '-ar-' suppresses the causer in semantic structure, without projection to the syntactical structure. Through this manipulation, transitive verbs come to have an intransitive function.

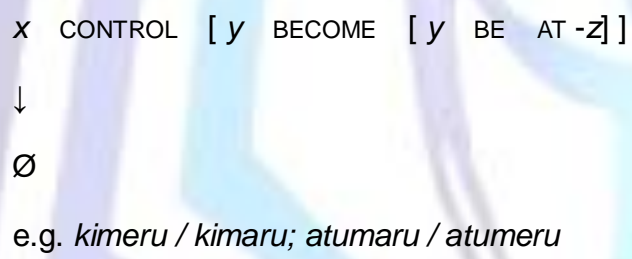

For instance, Japanese 開くhiraku ( e.g.ドアが開く; ドアを開く) and Chinese 开kāi (e.g. 门开men-kai,开门kai -men)indicate a change of state that takes place spontaneously. This is anticausativisation. As for decausativisation, the Chinese $\mathrm{t} \rightarrow$ 切好 gives an illustration.

The study of anticausativisation and decausativisation in Japanese and Chinese is of particular interest is due to the following reason: Japanese and Chinese fall into two different language families, i.e. Japanese is considered an agglutinating language while Chinese is an isolating language, the two share similarities at least in two aspects: (i). transitive and intransitive verbs share the same word form, c.f. (1), (2); (ii) intransitive and transitive verbs can derive from the same adjective stems. For example, the intransitive verb fukumaru is derived from the adjective fukai; the corresponding verb in Chinese is: adding a light verb bian to the adjective shen, thus forming intransitive verb bian-shen. On the other hand, fukameru is a transitive verb that derives from the adjective fukai; the corresponding verb in Chinese is: adding a light verb jia to the adjective shen and form an intransitive verb jia-shen. The derivations is summarised in Table 1. The Chinese verbs are put in Italics. 
Table 1. Adjective-derived verb pairs in Japanese and Chinese

\begin{tabular}{|l|l|}
\hline Intransitive verb & Transitive verb \\
\hline fukam-ar-u & fukam-e-ru \\
\hline bian-shen (become deep) & jia-shen (deepen) \\
\hline atatam-ar-u & atatam-e-ru \\
\hline bian-re (become warm) & jia-re (make it warm) \\
\hline
\end{tabular}

The above are preliminary illustrations that inspire us to investigate the phenomenon of transitive/intransitive verb alternation in more depth. In this paper, the following three issues are to be discussed:

(I) Lexical and syntactic strategies of anticausativisation as well as decausativisation in the two languages.

(II) To what extent that the two languages share similarities in terms of transitive/intransitive alternation.

(III) Decausativisation seems mostly conveyed via verb compounds (V-V) in Chinese. This inspires us to ponder how decausativisation actually manipulates.

The analysis will follow the argument structure as a point of departure and incorporate lexical conceptual structure (LCS) to account for the similarities as well as distinctions of the two languages.

The data for Modern Japanese is from the corpus of Balanced Corpus of Modern Written Japanese by National Institute for Japanese language and linguistics. The data for Modern Chinese is adopted from the corpus of Modern Chinese constructed by the Center for Chinese Linguistics at Beijing University. See http://ccl.pku.edu.cn/. This paper also uses 'hand-made examples'. All data are judged by Japanese and Chinese native speakers.

This paper is organised as follows. Section 2 discusses anticausativisation and decausativisation in terms of monosyllabic verbs. Section 3 is devoted to anticausativisation and decausativisation in V-Vs. Section 4 makes a further step forward in the constraint of antidecausativisation and decausativisation. Section 5 introduces anticausativisation and decausativisation in constructions. Finally Section 6 highlights the distinctions of the two languages and concludes the paper.

\section{Transitive/intransitive verb alternation with regard to monosyllabic verbs}

A list of 322 unaccusative, ergative and unergative verbs in Japanese and Chinese was produced. The following features in terms of transitive/intransitive alternation are observed:

(I) The Japanese morpheme '-e-' is used with both intransitive and transitive verbs. In

decausativisation, '-ar-' is most frequently used, but other affixes are also acceptable. 
e.g. //nur-e-ru//-//nur-as-(r)u//, //kak-ar-(r)u //-//kak-e-ru//, //or-e-ru//-//or-ø-(r)u//,

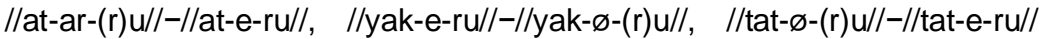

(II) Japanese intransitive morpheme '-ar-' appears to correspond to ergative verb in Chinese.

(III) The Japanese morpheme '-ar-' represents intransitive verb, the morpheme of its transitive verb is '-ø-(-u)'or '-e-'.

(IV) The Japanese morpheme '-i-' represents intransitive verb, the morpheme of its transitive verb is '-ø-(-u)' or '-os-(-osu)'/ '-as-(-asu)'.

(V) If the morpheme of transitive verb is '-ø-(-u)', then the morpheme of its intransitive verb would be '-e-'.

(VI) If the morpheme of intransitive verb is '-e-', then the morpheme of its transitive verb would be '-as-(-asu)' or-s- '(-su)'.

(VII) Japanese anticausativisation is realised through the affix '-e-', e.g. 切れる (kir-e-ru)/切る (kir-ø-(r)u)；折れる (or-e-ru) / 折る (or-ø-(r)u). The LCS of 「切れる/切る」 are given in (9).

(9)
a. $x$ CONTROL

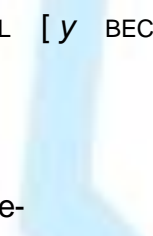
$\left[\begin{array}{llll}y & \text { BE } & \text { AT- } & z\end{array}\right] \quad(x=y)$
(切れる kir-e-ru)
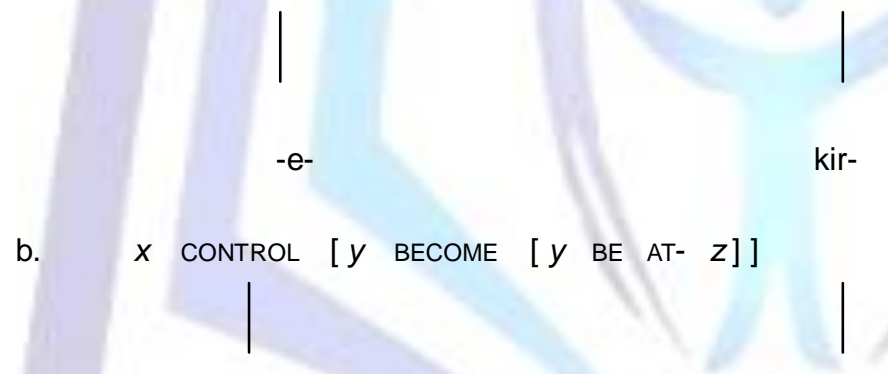
(切る kir- $\varnothing-(r) u)$ kir-

(VII) Japanese transitive verbs such as ukurama-su; chi-rasu and nayama-su in Chinese are realised through a syntactical causation: shi...pengzhang; shi...diaoling; shi...fannao. These observations are summarised in Table 2.

Table 2. A comparison of intransitive/ transitive verbs in Japanese and Chinese

\begin{tabular}{|c|c|}
\hline Intransitive verb & Transitive verb \\
\hline -i-/-os- ot-i-ru & ot-os-u \\
\hline luo & shi...luo-xia \\
\hline -e-/-akas- obi-e-ru (become frightened at) & obiy-akas-u \\
\hline pa/hai-pa & shi...hai-pa \\
\hline
\end{tabular}


(IX) Chinese transitive/intransitive verb alternation can be realised via the same verb form with different intonations. 转 'zhăn' is a transitive verb and it corresponds to Japanese transitive verb mawa-su (e.g. goma o mawasu 'spin a top') ; 转 'zhuàn' is an intransitive verb and it corresponds to Japanese intransitive verb mawa-ru (e.g. goma ga mawaru 'the top is spinning' ) . Other examples include ‘折’ zhé, a transitive verb that corresponds to Japanese transitive verb 折る; ‘折’ shé is intransitive, corresponding to Japanese intransitive verb「折れる」.

Moreover, Japanese intransitive verb derives from transitive verb via an intransitive suffix '-e-'. The Chinese corresponding intransitive verb to 切れる is ‘断 duan'. The corresponding transitive verb to 切る can be “剪 jian (cut with a scissor) ; or 切 qie (cut with a knife). This is summarised in Table 3.

Table 3. A comparison of anticausativisation in Japanese and Chinese

\begin{tabular}{|l|l|}
\hline Intransitive verb & Transitive verb \\
\hline 切れるkir-e-ru & 切るkir-ø-(r)u \\
\hline 断duan & 剪jian / 切qie \\
\hline
\end{tabular}

The LCSs of Chinese intransitive and transitive verb pair are given in (10) and (11).

(10)

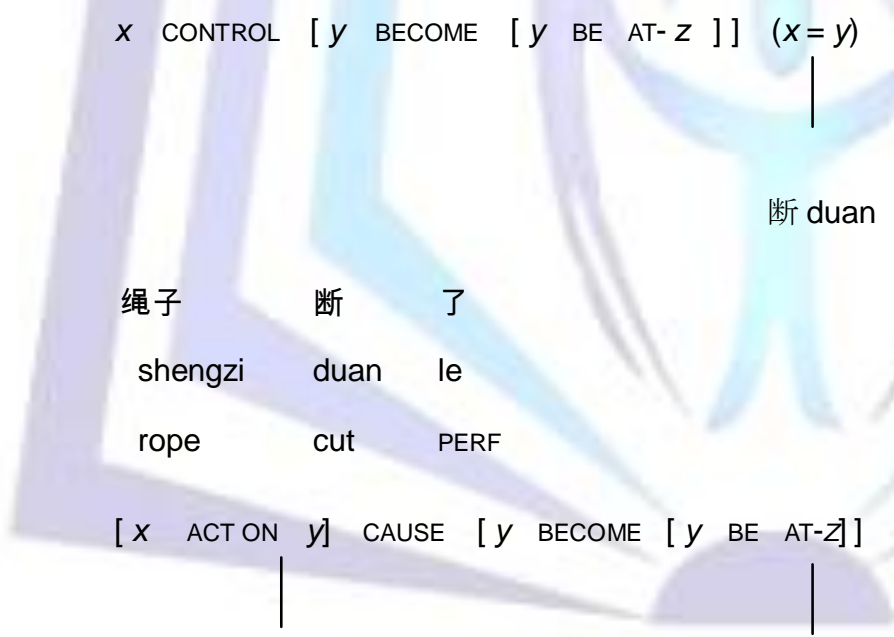

剪 jiăn / 切 qiē

$\varnothing$

It seems that, in Chinese, there is no derivational relationship between unaccusative veb '断 duan' and transitive verbs 剪 jian or 切 qie.

Kageyama (1996) indicates that in LCS, Japanese suffix '-e-' can identify the agent and the object. Thus the internal argument as well as the external argument can be identified. As a result, anticausativisation occurs, with the verb transiting from transitive to intransitive. This strategy, however, exist neither in Chinese nor in English. English cut and Chinese “砍 
kan' denote an event that implies an instrument and thus involve a strong agentivity. Thus, it appears hard to identify the agent and object, which further obstructs the anticausativisation.

Moreover, due to the manipulation of anticausativisation, Japanese action verbs seem easy to be intransitivised (12a). Whilst, it is impossible for English or Chinese monosyllabic action verb to reach the intransitivisation, due to the lack of anticausativisation, c.f. (12b), (12c).

a.＼cjkstart彼女はケーキを焼いた

Kanojo wa keiki o yaita

b. She baked a cake.

c. 她烤了

Ta kao le

she bake PERF
一个

yige

\section{～ケーキが焼けた}

keiki ga yaita.

$\rightarrow \quad{ }^{\star}$ A cake baked.

$\rightarrow$ *蛋糕烤

Dangao kao

cake

bake PERF

To summarise briefly, anticausativisation in Japanese is an important strategy for transitive/intransitive verb alternation. It is facilitated at morphological level. By contrary, very few Chinese monosyllabic verbs seem to have anticausativisation. The strategy is mostly reached at semantic level.

\section{Transitive/intransitive verb alternation with regard to verb compounds}

This section moves on to transitive/intransitive verb alternation with regard to verb compounds. As touched upon in Section 1, decausativisation in Chinese is can be realised via the schema: [action + resultative state]. To be specific, the strategy is: adding a resultative complement (e.g. 好hao, 满man, 光guang) to an action verb; the addition of such complements represent perfect of the action and can suppress the external argument. This is given in (13).

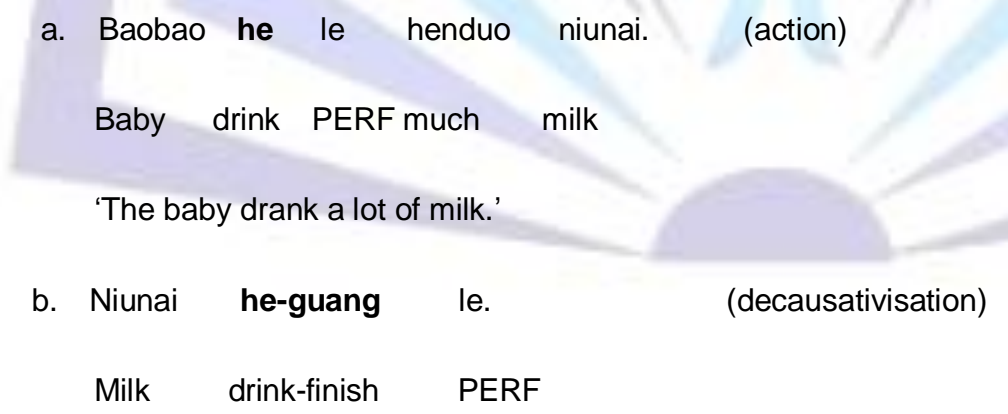

'All the milk was drunk.'

He-guang in (13b) is the result of the action 喝he in (13a), with the external argument Baobao suppressed. By adding a resultative complement, the focus of the event transits from causative to resutative; thus gives rise to decausativisation. The transition process can be described as follows:

The addition of resultative complement $\rightarrow$ suppress of the agent $\rightarrow$ decausativisation 
The LCS of Chinese decausativisation is as follows:

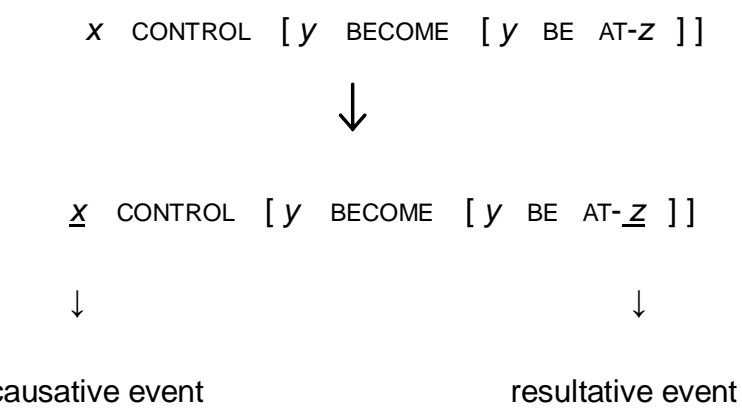

Table 4 provides a comparison of decausativisation in Japanese and Chinese.

Table 4. Decausativisation in Japanese and Chinese (schema-based strategy)

\begin{tabular}{|c|c|c|}
\hline Transitive verb -e- & Intransitiv & -ar- \\
\hline som-e-ru (dye) & som-ar-u & [morphological strategy] \\
\hline ran & ran cheng & [action + resultative state] \\
\hline u-e-ru (plant) & uw-ar-u & [morphological strategy] \\
\hline zhong & zhong hao & [action + resultative state] \\
\hline
\end{tabular}

In fact, most of the decausativisation is seen in verb compounds. As such, we are in the position to look into the nature of Chinese V-Vs. First of all, there are five variations in composing Chinese V-Vs:

(14) a. Transitive verb+Object (Predicate-Object Type)

e.g. jie-hun 'marry'

b. Predicate+Resultative complement (Predicate-Complement Type)

e.g. ku-shi 'cry-wet'

c. Modifier+Predicate (Modifier-Head Type)

e.g. chi-dao 'be late'

d. Subject+Predicate (Subject-Predicate Type)

e.g. tou-teng 'head-pain'

e. Coordinative Type

e.g. fa-sheng 'happen' 
We collected 115 illustrations of the five types $\mathrm{V}-\mathrm{V}$ by corpus. The percentage of each $\mathrm{V}-\mathrm{V}$ that gives rise to decausativisation is given in Table 5 .

Table 5. Types of Chinese verb compounds along with the possibility of decausativisation

\begin{tabular}{|l|c|}
\hline Type of Verb Compound & Percentage of transitive/intransitive alternation \\
\hline Predicate-Object Type & 0 \\
\hline Predicate-Complement Type & $60 \%$ \\
\hline Modifier-Head Type & $6.1 \%$ \\
\hline Subject-Predicate Type & $0 \%$ \\
\hline Coordinative Type & $33.9 \%$ \\
\hline
\end{tabular}

As confirmed from the database, the Predicate-Object Type and the Subject-Predicate Type only bear an intransitive function. The reason lies in that: Predicate-Object $\mathrm{V}-\mathrm{V}$ is composed from a verb and an object. Therefore, in its syntactic structure, the compound is unable to take another object. We consider it fully lexicalised. Subject-Predicate V-V appears more like a noun phrase and is also fully lexicalised. Only Predicate-Complement Type, Modifier-Head Type and Coordinative Type of V-Vs are possible for decausativisation. And among them, Predicate-Complement V-V has the largest occupation. In the following paragraphs, Predicate-Complement V-V will be tackled in detail.

In Predicate-Complement V-V, V1 usually denotes an action and V2 indicates the result or state. For example, 剪jian is a transitive verb, when followed by an adjective or middle intransitive verb, it comes to have intransitivity. The manipulation is given in (15). $x$ CONTROL $\left[\begin{array}{lll}y & \text { BECOME }\end{array}\left[\begin{array}{lll}y & \mathrm{BE} & \mathrm{AT}-\underline{z}\end{array}\right]\right.$

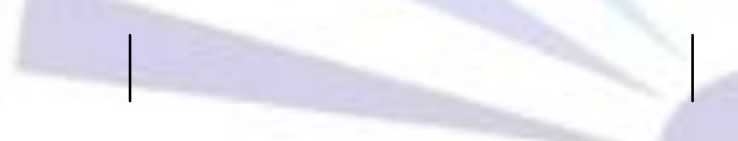

剪 jian / 切 qie 断 duan

e.g. a. Zhang San ba sheng-zhi jian-duan le

'Zhangsan cut the cord.'

b. sheng-zhi bei jian-duan le

'The cord was cut/broken.'

Since decausativisation is mainly conveyed via predicate-complement V-V, it is worthwhile taking a further look at it. Shen (2007) classifies predicate-complement V-V into four types, based upon argument structure.

(16) a. Unaccusative $V+$ Unaccusative $V$ 
醉倒 zui-dao

累坏 lei-huai

b. Unergative V + Unaccusative V/Adj

唱哑 chang-ya

哭累 ku-lei

c. Transitive $\mathrm{V}+$ Unaccusative $\mathrm{V}$

推开 tui-kai

打破 da-po

d. Transitive $V+$ Stative predicate

听懂 ting-dong

学会 xue-hui

Shen (2007)

Note that (16b) [unergative $\mathrm{V}+$ unaccusative $\mathrm{V} / \mathrm{Adj}$ ] and (13d) [transitive $\mathrm{V}+$ stative predicate] are external-argument oriented and therefore is not possible for decausativisation.

In addition, the Japanese V-Vs corresponding to [unaccusative $\mathrm{V}+$ unaccusative $\mathrm{V}$ ] and [transitive $\mathrm{V}+$ stative predicate] are participle complex predicates, i.e. use a manner verb in the -te participial form and a path verb to conflate both manner and path in a single clause, as in (17). Yoneyama (1986:2) refers to them as 'complex verbs'.

(17) a. Unaccusative $V+$ Unaccusative $V$

Chinese V-V: 醉倒 zui-dao

Japanese Complex V: 酔って倒れる yottetaoreru (drunk-fall) /酔わせて倒させる

yowasetetaosaseru (make drunk and make fall)

b. Transitive $\mathrm{V}+$ Stative predicate

Chinese V-V: 听懂 ting-dong

Japanese Complex V: 聴いて理解する kiiterikaisuru (listen-understand)

\section{Constraint on decausativisation and anticausativisation}

This section is denoted to the constraint of antidecausativisation and decausativisation. We begin by looking at anticausativisation. 


\subsection{Constraint on anticaustivisation}

As touched upon in previous sections, Chinese anticausativisation is mainly realised by verb compounds. We are now in the position of looking at the constraint of anticausativisation. Considering the following three illustrations.

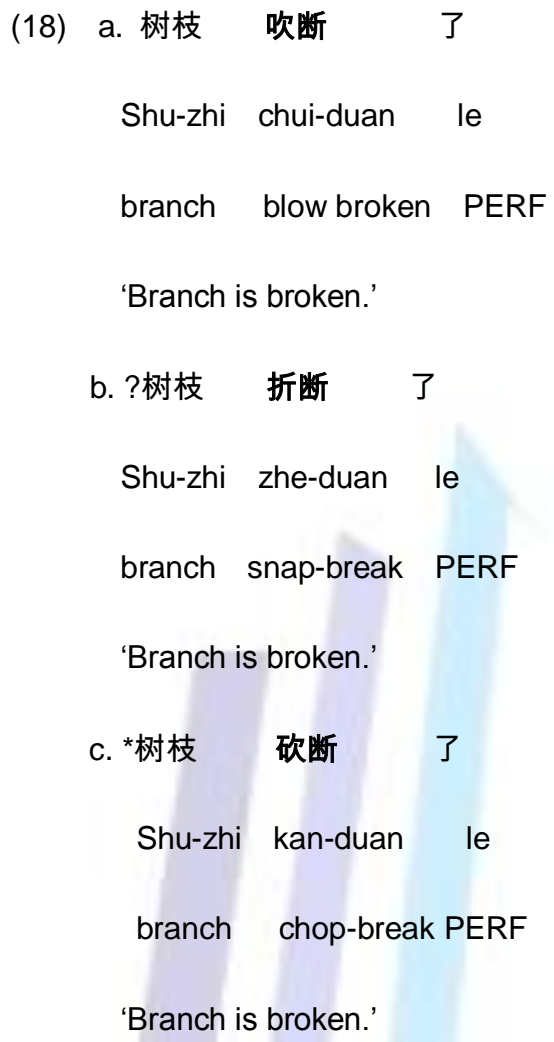

The different acceptabilities of verbs '吹chui (blow)', ‘折zhe (snap)', ‘砍kan (chop)' in the above sentences is due to the following reason: the $V-V$ '吹断chui-duan' is subjected by wind, thus denoting a spontaneous phenomenon. The $V$ - $V$ '砍断 kan-duan (chop)' involves an instrument, therefore the object does not change in terms of the property of the object itself and thus fails to identify the object and the causer. The agentivity of 折断 zhe-duan is in-between 吹断 and 砍断, therefore the acceptability is also among them.

In fact, this constraint also applies to English:

(19) a. The kids splashed/smeared mud on the wall.

b. The mud splashed $/{ }^{*}$ smeared on the wall.

At this stage, perhaps we can a draw a primary conclusion: when a resultative complment predicate an internal argument, the higher the agentivity that implies manner of action, the greater the unlikelihood of anticausativisation. This is summarised in Figure 1. 


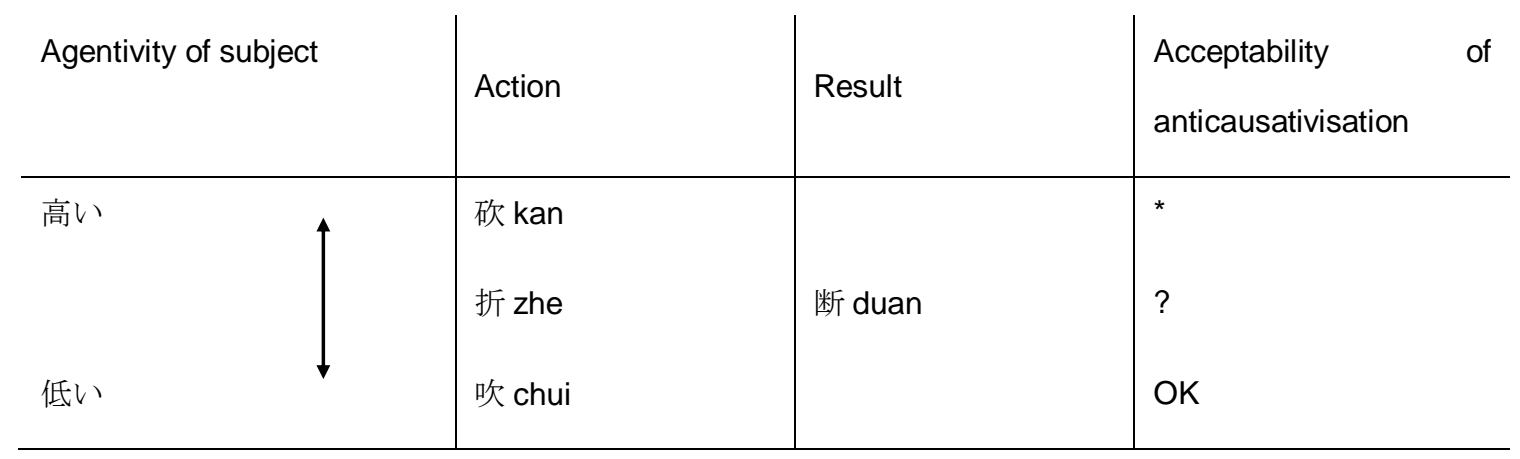

Figure1. Acceptability of anticausativisation along with the agentivity of subject

\subsection{Constraint on decaustivisation}

In Japanese and English, it seems that the predication of a resultative predicate is limited to the internal argument. It has to be the subject of an ergative verb in a resultative construction, c.f. (20); subjects of transitive verb or unergative verb are ruled out, c.f. (21a) and (21b).

(20) a. The jelly froze solid.

b. ゼリーはカチカチ に凍った.

Zerii wa kachikachi ni kootta

Jelly TOP solid DAT freeze-PAST

(21) a. *He cried tired.

b. *彼はくたくたに泣いた.

Kare wa kutakuta ni naita

He TOP tired DAT cry-PAST

In terms of Chinese, consider the following contrasting illustrations. (22) is [internal argument-predicate] type, describing the object; (23) is [external argument-predicate] type, indicating the subject.

\section{(22) Internal argument-predicated type}

a. Wo xie-huai le zhezhi bi.

I write-broken PERF this pen

'I write with the pen and it is broken.'

b. Zhezhi bi xie-huai le. (decausativisation: OK)

this pen write-broke PERF

'The pen is broken.' 
When the resultative predicate is 'external argument', then, decausativisation becomes impossible (23b). English presents a similar phenomenon, c.f. (23c).

\section{(23) External argument-predicated type}

a. Wo xie-guan le zhezhi bi.

I write-used to PERF this pen

'I got used to writing with this pen.'

b. *Zhezhi bi xie-guan le. (decausativisation: ruled out)

this pen write-used to PERF

c. *'The pen is used to be written.'

In decausativisation, the internal argument that accepts the change of state is constrained on 'possessive relationship'. Mochizuki (2004) claims that the subject of an urgative verb can only be a part of the body. In this case, both Chinese and Japanese can be possible since they extensively employ verb compounds (c.f. 24, 25) ${ }^{1}$.

(24) a.Wo ku-zhong le shuangyan.

I cry-swell PERF eyes

'I cried out my eyes.'

b. Wo-de shuangyan ku-zhong le.

(decausativisation)

I GEN eyes cry-swell PERF

(25) a. Watashi wa ryoogan o naki-harashita.

I TOP eyes ACC cry-swell PERF

b. Watashi-no ryoogan ga naki-hareta.

(decausativisation)

I GEN eye NOM cry-swell PERF

When the subject of an urgative verb is not a part of the body (27), decausativisation turns impossible in Chinese or Japanese.

(26) Transitive structure

a. 狗

吠醒

了他们.

Gou

fei-xing

le

tamen

1 The illustrations of (26) (29) are based upon Levin \& Rapparport Hovov (1995: 36) and Mochizuki (2004). 
dog bark-awake PERF them

b. 犬は彼らを 吠え起こした

inu wa karera o hoeru-okiru PERF

(27) Decausativisation

a.*他们 吠醒 了.

tamen fei-xing le

they bark-awake PERF

b. *彼らは 吠え起きた.

\section{Anticausativisation and decausativisation in constructions}

So far, transitive/intransitive verb alternation in monosyllabic verbs as well as compound verbs is examined. It would not be unsound to take a further look into anticausativisation and decausativisation in constructions.

\subsection{Decausativisation in Chinese 'Existential Construction' (Place+Verb + zhe +Theme)}

It is observed that two types of constructions give rise to decausativisation in Chinese. The first one is 'existential construction', which in English is named 'locative inversion construction', in Japanese is called 'Te-aru construction'. The other type of decausativisation construction is: add a goal or source to the change-of-location verbs.

Decausativisation in existential construction has the following composition: [Place+Verb +着 $(z h e)+$ Theme]. In this construction, the external argument is suppressed by subjectivisation of the location, c.f. (28b).

(28)

$\begin{array}{lllll}\text { a. 墙上 挂 } & \text { 着 } & \text { 一幅 } & \text { 画 } \\ \text { Qiángshàng guà } & \text { zhe } & \text { yīfú } & \text { huà } \\ \text { Wall-on hang } & \text { ASP } & \text { one-CL } & \text { picture }\end{array}$

'A painting is hanging on the wall.'

$$
\begin{array}{ccc}
\text { c.f. b. 一幅画 } & \text { 挂在 } & \text { 墙上 } \\
\text { Yī-fú-huà } & \text { guà-zài } & \text { qiángshàng } \\
& & \\
\text { one-CL-picture hang-ASP } & \text { wall-on }
\end{array}
$$

'A painting is hanging on the wall.'

The distinction between (28a) and (28b) can be explained from an information structure perspective. 墙上 qiang-shang 'wall' in (28a) is old information, i.e. Ground, and 画 hua 'picture' is new information, i.e. Figure.

(29) a. PPLOC V 着/了/满 O

b. $\mathrm{O} V$ 在 PPLOC 
With aspectual markers (e.g. ‘着 zhe/了 le/满 măn') or resultative complements, the focus of construction transits from the causative event to the location whereby the result of action appears.

\subsection{Decausativisation in Japanese 'Te-aru construction'}

With regard to Japanese, the syntactic manipulation of backgrounding the agent is 'Te-aru construction', as in (30).

$\begin{array}{cccc}\text { (30) 庭に } & \text { 木姩 } & \text { が } & \text { 植えてある. } \\ \text { Niwa ni } \quad \text { Mokusei } & \text { ga } & \text { ue-te-aru } \\ \text { Yard DAT Osmanthus fragrans } & \text { NOM } & \text { plant }\end{array}$

'A osmanthus fragrans is planted in the yard.'

According to Kageyama (2000), 'Te-aru construction' emphasises the existence of the result of certain action. It backgrounds the agent (external argument) and foregrounds the object (internal argument).

It should be further noted that the 'aru' in the 'Te-aru construction' appears the same suffix '-ar-' in transitive/intransitive verb alternation pair, e.g. kakeru-kakaru. But the two are different. The agent of the intransitive verb '-ar-' only bears a semantic function thus the agent does not exist in syntactic structure. On the other hand, 'Te-aru construction' is a syntactic construction, and therefore, the external argument does exist; only being an implicit argument (Kageyama 2000).

\section{Conclusion}

This paper is dedicated to comparing transitive/intransitive verb alternation in Japanese and Chinese. Discussions are focused upon three grammatical elements: monosyllabic verbs, compound verbs and constructions. The findings reveal that the two languages share similarities in two aspects: (i). transitive and intransitive verbs share the same word form; (ii) transitive and intransitive verbs can derive from the same adjective stems. Significant distinctions are also seen between the two: anticausativisation and decausativisation in Japanese are mainly facilitated in morphological level, e.g. anticausativisation is realised through the morpheme '-e-' and decausativisation is conveyed by '-ar-'. The morpheme '-e-' can be used with both intransitive and transitive verbs. Regarding Chinese, lexical and syntax have a curial role to play in transitive/intransitive verb alternation. The LCS of Chinese, together with Japanese anticausativisation is given below.
a. $x$ CONTROL $\left[\begin{array}{lllll}y & \text { BECOME }\end{array}\left[\begin{array}{lll}y & \mathrm{BE} & \mathrm{AT}-\underline{z}\end{array}\right] \quad(x=y)\right.$
$-\mathrm{e}-$
war-
$\varnothing$
碎 sui
b. $x$ CONTROL $[y$ BECOME $[y$ BE AT- $\underline{z}]]$

$-\varnothing-$

打 da war-

碎 sui 
Decausativisation appears the most favourable strategy of Chinese transitive/intransitive verb alternation and is mainly facilitated in lexical and syntactic level:

\section{Lexical manipulation of decaustivisation:}
a. Monosyllabic verbs + aspectual complements
b. action $\mathrm{V}+$ resultative predicate

\section{Syntactic manipulation of decaustivisation:}
a. Existential construction: PPLOC V 着/了/满 O
b. 「在 zai」construction: $\mathrm{O}$ 在 PPLOC

Chinese decausativisation is realised via two ways, i.e. the schema of [action + resultative state] or, by verb compounds. Three types of V-Vs are possible for this strategy, i.e. Predicate-Complement V-V, Modifier-Head V-V and Coordinative V-V. Among them, predicate-complement type of $\mathrm{V}-\mathrm{V}$ has the largest token of decausativisation. The LCS and argument structure of predicate-complement $\mathrm{V}-\mathrm{V}$ is as follows.

a.

\section{Argument structure}

b. Argument structure
[Agent]

[Theme]

$\left[\begin{array}{ll}x & \mathrm{ACT}\end{array}\right]$

$\left[\begin{array}{lll}y & \mathrm{BE} & \mathrm{AT}-z\end{array}\right]$

[Agent, Theme]

LCS

$$
\left[\begin{array}{ll}
x & \mathrm{ACT}
\end{array}\right] \text { CAUSE }\left[\begin{array}{lll}
y & \mathrm{BECOME}
\end{array}\left[\begin{array}{lll}
y & \mathrm{BE} & \mathrm{AT}-\boldsymbol{z}
\end{array}\right]\right.
$$

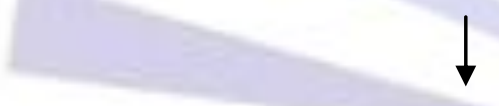

$\emptyset$ (Decausativisation)

Furthermore, constraints on Chinese anticausativisation and decausativisation are seen. When a resultative complment predicate an internal argument, the higher the agentivity that implies manner of action, the greater the unlikelihood of anticausativisation. In decausativisation, the internal argument that accepts the change of state is limited to the 'possessive relationship'.

\section{REFERENCES}

[1] Kageyama, Taro. 1993. Bunpou to gokeisei. Hitsuji Shobo Publishing.

[2] Kageyama, Taro. 1996. Doushiimiron-gengo to ninchi no setten. Kuroshio. 
[3] Kageyama, Taro. 1999. Word formation. In The Handbook of Japanese Linguistics, ed. Natsuko Tsujumura. Malden, MA: Blackwell Publishers.

[4] Levin, Beth and Malka Rappaport Hovav. 1995. Unaccusativity: At the Syntax-Lexical Semantics Interface. Cambridge, Massachusetts, The MIT Press.

[5] Maruta, Tadao. 1998. Shiekidooshi no anatomi: goitekishiekidooshi no goigainenkoozoo. Shoohakusha Publishing.

[6] Mochizuki, Keiko. 2004. Nihongo to Chuugokugo ni okeru shiekikidookoutai. Kenkyuusha Publishing.

[7] Okutsu, Keiichiroo. 1967. Jidooshika, tadooshika oyobi ryookokuka henkei. Kokugoogaku 70: 46-65, Meijishoin. Tokyo.

[8] Suga, Kazuyoshi. 2000. Nihongodooshi no jitataioo ni okeru imi to keitai no kankei, in Maruta Tadao \& Suga Kazuyoshi (eds), Nichieigo no jita no koutai. 71-110. Hitsuji Shoboo.

[9] Shen, Yamin. 2007. Chuugokugo no kekkafukugoodooshi no kookoozoo to goigainenkoozoo, Lexical Forum 3, $195-229$.

[10] Yoneyama, Mitsuaki. 1986. Motion verbs in conceptual semantics. Bulletin of the faculty of Humanities 22, 1-15. Seikei

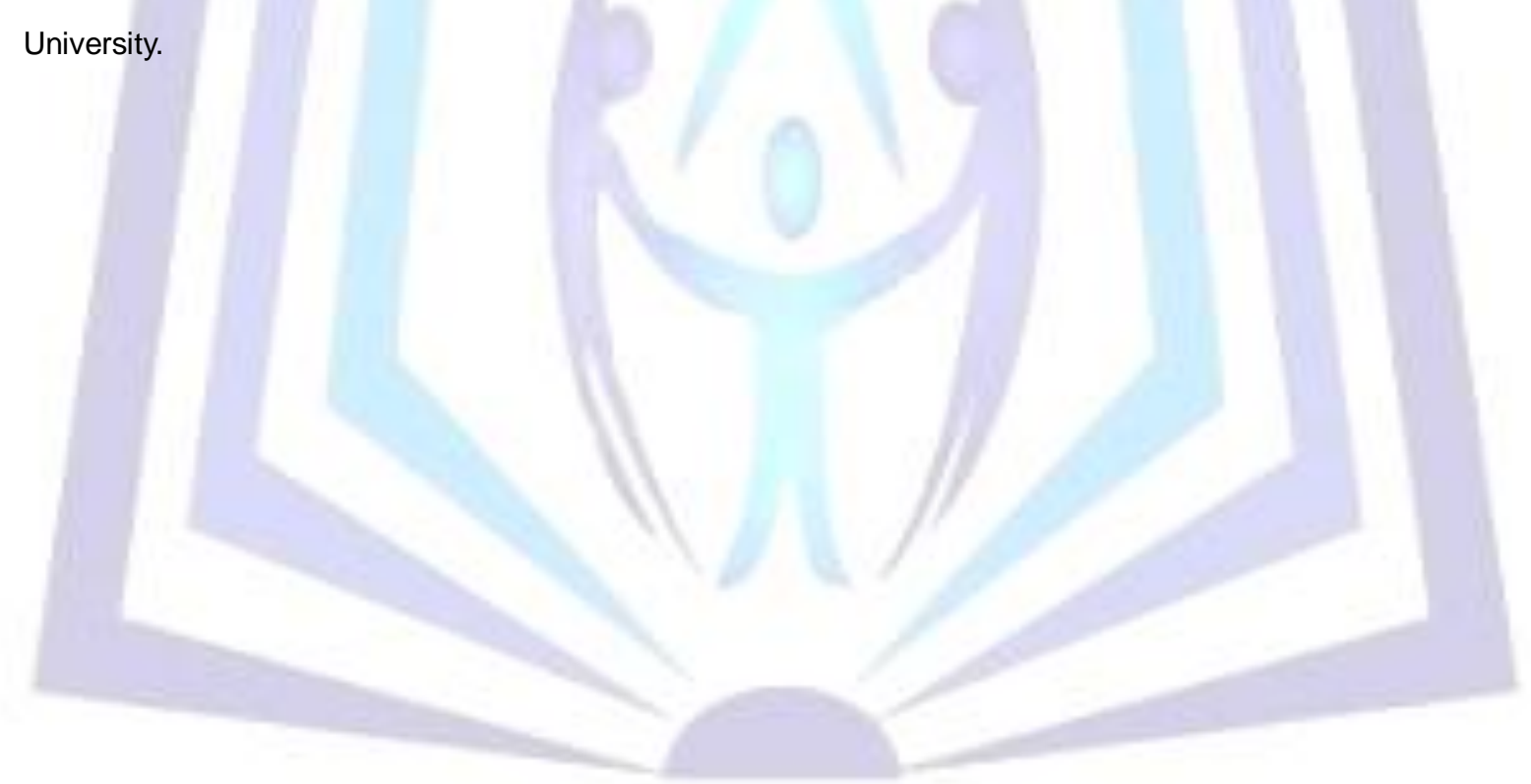

